\title{
Does the United States Need an Official Language?: The Examples of Belgium and Canada
}

\section{INTRODUCTION}

Language is the essential medium of expression upon which all cultures depend. Most peoples and cultures do not willingly accept intrusion upon their rights to use their native language. At the same time, most nations in the world are composed of more than one language group, ${ }^{1}$ and many, including the United States, have experienced conflict between groups. The current conflict in the United States is between those wishing to ensure the continued dominance of English and those linguistic minorities who desire to retain basic legal rights in their native tongues.

This Note will first examine current language policy in the United States in the areas of civil rights, education, voting rights, and employment. Following a review of the controversy surrounding the prospective designation of an official language in the United States, this Note will compare language policy in the United States with the policies developed in the two nations best known for the resolution of their significant language conflicts, Belgium and Canada.

\section{Current Linguistic Problems in the United States}

While the United States has long envisioned itself as a melting pot of immigrants from varying ethnic and cultural backgrounds, ${ }^{2}$ this vision of unity has been widely reexamined in recent years. Recent immigrants are perceived as less willing to abandon their native lan-

1. J.A. Laponce, Languages and Their Territories 95 (1987).

2. For a discussion of the history of linguistic groups and assimilation in the United States, see Edward Sagarin \& Robert J. Kelly, Polylingualism in the United States of America: A Multitude of Tongues Amid a Monolingual Majority, in Language Policy and National Unity 20, 36-37 (William R. Beer \& James E. Jacob eds., 1985) [hereinafter Language Policy]; see generally Bill Piatt, Only English?: Law and Language Policy in the United States 26 (1990); Harvey A. Daniels, The Rools of Language Protectionism, in Not Only English: Affirming America's Multilingual Heritage 3-4 (Harvey A. Daniels ed., 1990) [hereinafter Not Only English]; Dennis Baron, The EnglishONLY Question 8 (1990). 
guages in order to assimilate into mainstream American culture. ${ }^{3}$ The reaction has been a widespread call for restricting the use of languages other than English. ${ }^{4}$

Critics of language initiatives contend that laws restricting the use of languages other than English in public notices or in the extension of public services will impair access to these services by members of minority language groups with limited English skills. ${ }^{5}$ Language restriction legislation has also been criticized as discriminatory because it can create barriers to the exercise of such rights as voting and education. ${ }^{6}$ The issue of an official language for the United States evokes great passion from both sides. Both sides fear disenfranchisement, alienation, and discrimination on the basis of the language they speak. Both sides are concerned with language maintenance, but differ as to what sacrifices this maintenance should incur. Proponents of English as the official language wish to preserve English in what they perceive as its traditional role: a medium of communication that helped guarantee unity and equality among a predominantly immigrant population. Opponents of an official language designation, however, often feel that the designation of an official language will accord that language the powerful status of an exclusive force: the official language to the exclusion of all others.

\section{A. Current Legislation in the States}

It is undisputed that English is the dominant language of government and commerce in the United States. Nevertheless, English is not

3. BARON, supra note 2, at 8 , noting that:

[e]stablished ethnic groups perceive each new wave of immigrants as qualitatively different in its willingness to join the melting pot. In the nineteenth century, Germans and Scandinavians were often regarded by the AngloSaxon population as dangerous foreigners who were both racially distinct and bent on keeping their distance from American culture. In the early part of the twentieth century, newcomers from southern and eastern Europe were judged less adaptive to the American language and way of life than the northern and western Europeans who, after several generations in the New World, were finally shedding the linguistic trappings of their ethnicity. Today the same charges of unwillingness to assimilate are leveled at Hispanic and to a lesser extent at Asian Americans, despite linguistic evidence which shows that the children of these immigrants still learn English at an impressive rate.

4. The current demands for language restrictions are not unique to United States history. Various attempts at language restriction, such as bans on the use of German during World War I, have been made in the past. BARON, supra note 2, at 9.

5. See Laura A. Cordero, Constitutional Limitations on Official English Declarations, 20 N.M. L. REv. 17, 18 (1990).

6. See generally PiATr, supra note 2 , at 167-78. 
and has never been designated as the nation's official language. However, the number of statutes regarding the official use of English among the states ${ }^{7}$ has greatly increased since $1981 .{ }^{8}$ Some state legislation has been described as merely symbolic because the statutes have been drafted to resemble other symbolic acts such as the declaration of a state flower or bird. ${ }^{9}$ In other states, such as Alabama and California, legislation has been drafted which restricts the legislature's power to make laws that "diminish or ignore the role of English as the common language of the state." 10 These states also created citizens' rights to enforce official English declarations in the courts. ${ }^{11}$

\section{B. Federal Language Policy}

The federal government, by contrast, has not yet enacted legislation to make English the nation's official language. Federal policy on language does exist, however, in such areas as civil and voting rights, employment, and education. Federal language policy is not a product of direct regulation to grant official status to minority languages. Instead, federal policy has generally protected language minorities where failure to recognize linguistic diversity would have resulted in discrimination or the denial of basic rights.

\section{Civil Rights}

The Civil Rights Act of 1964 has been credited with advancing the opportunities for bilingual education for children of linguistic minorities. ${ }^{12}$ Title VI of the Act is the key by which courts could open

7. Kathryn J. Zoglin, Recognizing a Human Right to Language in the United States, 9 B.C. Third World L.J. 15, 16 (1989).

8. Ala. Const. amend. 509; Ariz. Const. art. XXVIII, 1 ; Ark. Code Ann. \$1-4-117 (Michie Cum. Supp. 1991); Cal. Const. art. III, $\$$ 6; Colo. Const. art. II, \30a; Fla. Const. art. II, $\$ 9 ; 1986$ Ga. Laws 70; Ill. Rev. Stat. ch. 1, para. 3005 (1989); Ind. Code $\$ 1-2-10-1$ (1988); Ky. Rev. Stat. AnN. $\$ 2.013$ (Michie/ Bobbs-Merrill 1985); Miss. Code Ann. 3-3-31 (1991); Neb. Const. art. I, $\$ 27$; N.C. Gen. Stat, \$145-12 (1990); N.D. Cent. Code \$54-02-13 (1989); S.C. Code Ann. I-1-696 to 1-1-698 (Law. Co-op. Cum. Supp. 1991); Tenn. Code Ann. S 4-1-404 (1991); VA. Code AnN. 22.1-212.1 (Michie 1985).

9. BARON, supra note 2, at 24 (noting that the symbolic statutes of Arkansas and Illinois have "not restricted minority-language rights or interfered with the assimilation process").

10. See Zoglin, supra note 7 and accompanying text.

11. Id.

12. Marguerite Malakoff \& Kenji Hakuta, History of Language Minority Education in the United States, in Bilingual Education: Issues and Strategies 27, 31 (Amado M. Padilla, Halford H. Fairchild, and Concepción M. Valadez eds., 1990). 
the doors of bilingual education by prohibiting discrimination because of "race, color, or national origin." 13 While no case has "expressly held that language-based classifications discriminate on the basis of national origin discrimination, the equation of language with national origin has been consistently recognized." 14

\section{Bilingual Education}

The Bilingual Education Act (BEA) was enacted in 1968 to meet the needs of children of linguistic minorities. ${ }^{15}$ It "provided grants to promote research and experimentation for meeting the needs of children who demonstrated little or no proficiency in the English language." 16 Significantly, the BEA "defined bilingual education programs as falling within federal educational policy." In doing so, the BEA "marked a change of policy toward language minorities and undermined the Englishonly laws that were still on the books in many states.",18

In addition, the Department of Health, Education, and Welfare (HEW) implemented regulations and guidelines under Title VI of the Civil Rights Act which stated that "school systems are responsible for assuring that students of a particular race, color, or national origin are not denied the opportunity to obtain education generally obtained by the students in the system." A 1970 memorandum published in the Federal Register interpreted Title VI and its applicability to language minority students. School districts were specifically required to take "affirmative steps to rectify the language deficiency in order to open [their] instructional program[s] to these students." ${ }^{20}$ The guidelines did not indicate what those steps should be. ${ }^{21}$

13. Id. at 31 .

14. Cordero, supra note 5, at 26-27 (citing cases on linguistic exclusion: Meyer v. Nebraska, 262 U.S. 390, $398-99$ (1922) (discussing a Nebraska statute which mandated English as the only language of instruction and effectively singled out only children of foreign origin), Yu Cong Eng v. Trinidad, 271 U.S. 500, 524-25 (1926) (holding that a Philippine act prohibiting anyone from keeping accounting books in any language other than English, Spanish, or a local dialect was discriminatory against Chinese merchants), and Katzenbach v. Morgan, 384 U.S. 641,654 (1966) (discussing a New York literacy requirement motivated by racial animosity to Puerto Ricans)).

15. 20 U.S.C. 3281 (1988).

16. Piatt, supra note 2, at 43 .

17. Malakoff \& Hakuta, supra note 12 , at 32 .

18. Id.

19. Id. at 33 (quoting $33 \mathrm{Fed}$. Reg. 4956, (1968)).

20. Id.

21. Id. (citing 35 Fed. Reg. 11595) (1970)). 
Then in 1974, the Supreme Court affirmed the effect of the HEW guidelines in Lau v. Nichols. ${ }^{22}$ In a concurring opinion, Justice Stewart stated that the HEW guidelines correctly "require affirmative remedial efforts to give special attention to linguistically deprived children." ${ }^{23}$ The Court also stated that "there is no equality of treatment merely by providing students with the same facilities ... for students who do not understand English are effectively foreclosed from any meaningful education." 24 The Court, however, did not specifically require bilingual education as the remedy for solving educational deficiencies.

\section{Equal Educational Opportunity Act}

Congress extended the Lau decision to the states when it enacted the Equal Educational Opportunity Act of 1974 (EEOA) ${ }^{25}$ Section 1703(f) states that "[n]o state shall deny equal educational opportunities to an individual on account of his or her race, color, sex, or national origin, by ... the failure by an educational agency to take appropriate action to overcome language barriers that impede equal participation by its students in its instructional programs. ${ }^{26}$ In Castaneda v. Pickard, ${ }^{27}$ the United States Court of Appeals for the Fifth Circuit interpreted Section $1703(f)$ as giving federal courts jurisdiction to determine what constituted "appropriate action" under the EEOA. ${ }^{28}$ The court held that "appropriate action" should ensure that "the language barrier is being overcome," it did not specifically endorse bilingual education. ${ }^{29}$

States which have enacted bilingual education statute $s^{30}$ have generally followed the Lau decision. In other words, they either require

22. 414 U.S. 563 (1974).

23. Id. at 571 .

24. Id. at 566 .

25. 20 U.S.C. $\$ 1701(1988)$.

26. 20 U.S.C. $\$ 1703(\mathrm{f})(1988)$.

27. 781 F.2d 456 (5th Cir. 1986).

28. Malakoff \& Hakuta, supra note 12 , at 35 .

29. Castaneda, 781 F.2d 456, 470.

30. Alaska Stat. $\$ 14.30 .400$ (1975); Ariz. Rev. Stat. Ann. $\$ 15-752$ (1984); Cal. Educ. Code $\$ 52160$ (West 1981); Colo. Rev. Stat. $\$ 22-24-101$ (1988); Conn. Gen. Stat. Ann. $10-17$ a (West 1986); Del. Code Ann. Tit. 14, 122 (c) (1981); Ill. Rev. Stat. ch. 122, para. 14C-1 (1973); Ind, Code 20-10.1-5.5-1 (1976); Kan. Stat. Ann. 72-9501 (1985); LA. Rev. Stat. Ann. $\$$ 17:272, 17:273 (West 1982); Me. Rev. Stat. Ann. tit. 20A, $\$ 4701$ (1984); Mass. Gen. Laws Ann. ch. 71A (West 1982); Mich. Comp. Laws Ann. $\$ 380.1152$ (West 1988); Minn. Stat. Ann. $\$ 126.262$ (West Cum. Supp. 1992); N.H. Rev. Stat. AnN. 189:19 (1989); N.J. Rev. Stat. Ann. 18A:35-15 (1989); N.M. Stat. Ann. 22-23-1 (Michie 1978); N.Y. Educ. 
or specifically authorize bilingual programs which aid minority language students in acquiring English where the number of such students so warrants. ${ }^{31}$

\section{Voting Rights}

The Voting Rights Act of 1965 was enacted to protect the rights of all to vote under the Fourteenth and Fifteenth amendments. It currently prohibits states from providing "voting notices, forms, instructions, assistance, or other materials and ballots in English language only.",32 The Act was also intended to prevent language minorities from being denied access to the polls and the right to vote through the use of literacy tests as a condition to voting. ${ }^{33}$

\section{Employment}

Discrimination in employment generally is covered under Title VII of the Civil Rights Act of 1964 and under 42 U.S.C. $\ 1981$, which was originally enacted in $1870 .{ }^{34}$ Title VII, which is known as the Equal Employment Opportunity Act, prohibits employment discrimination primarily on the basis of race, color, religion, sex, or national origin. Both statutes have been used in determining the scope of language rights in employment. Under Title VII, the employee need generally only show "disparate impact upon a protected group"; however, "courts have found that a discrimination claim under 42 U.S.C. $\$ 1981$ requires proof of discriminatory intent." 35

While courts have recognized that employment discrimination on the basis of language or accent is prohibited as national origin discrimination, ${ }^{36}$ English-only rules in the workplace may be tolerated for

Law 3204 (McKinney 1981); Pa. Stat. Ann. tit. 24, 15 -1511 (Purdon Cum. Supp. 1991); R.I. Gen. Laws \$ 16-54 (1988); Tex. Educ. Code Ann. 21.451 (West 1987); Wash. Rev. Code Ann. $\$ 28 A .180 .010$ (1991); Wis. Stat. AnN. 115.95 (West 1991).

31. Malakoff \& Hakuta, supra note 12 , at 38.

32. 42 U.S.C. \1973aa-1a(b) (1988).

33. Cordero, supra note 5 , at $36-37$; For a discussion on literacy tests as prerequisites to voting, see BARON, supra note 2, at 58-61 and 123-25.

34. 42 U.S.C. $2000 \mathrm{e}-2$ (1988).

35. Piatt, supta note 2, at 63-64.

36. Bill Piatt, Toward Domestic Recognition of a Human Right to Language, 23 Hous. L. Rev. 885, 891 (1986)(citing Saucedo v. Brothers Well Serv. Inc., 464 F. Supp. 919, 920 (S.D. Tex. 1979); Carino v. University of Okla. Bd. of Regents, 750 F.2d 815, 819 (10th Cir. 1984)). 
valid business reasons. ${ }^{37}$ The 1988 decision in Gutierrez v. Municipal Court $^{38}$ recognized the rigorous business necessity standard promulgated in Equal Employment Opportunity Commission guidelines and followed the standard of review established in Robinson v. Lorillard Corp. ${ }^{39}$ The business necessity standard requires that the needs of an employer in imposing a rule "that has a disparate impact on groups protected by the national origin provisions of Title VII" be sufficiently justified under the 1964 Civil Rights Act. ${ }^{40}$

\section{Language of Government Act of 1991}

In January and February of 1991, identical bills were introduced in both houses of Congress to amend the United States Code and establish English as the official language of the United States government. ${ }^{41}$ The stated purpose of the proposed Language of Government Act is to "maintain the benefits of a single official language of the Government. ..."42 Although the proposed Act states that there is no intent to "discriminate against or restrict the rights of any individual," it does provide that,

[e]xcept where an existing law of the United States directly contravenes this Act (or the amendments made by this Act)(such as requiring the use of a language other than English for an official act of Government of the United States), no implied repeal of existing laws of the United States is intended..$^{43}$

Proposed Chapter 6, section 163 of the Act states that "[n]o entity to which this chapter applies shall make or enforce an official act that

37. Id. at 892, which discusses Garcia v. Gloor, 618 F.2d 264 (5th Cir. 1980), cert. denied, 449 U.S. 1113 (1981) (where Garcia was hired as a bilingual salesman, but was forbidden to speak Spanish except to customers. Garcia was fired for speaking with a co-worker in Spanish, and subsequently challenged the employer's rule under 42 U.S.C. 2000e-2(a). The district court denied Garcia's claim because it found that the rule was valid for business reasons. The Fifth Circuit affirmed without examining specifically the business reasons offered).

38. 838 F.2d 1031 (9th Cir. 1988).

39. Id. at 1044; The test established in Robinson is whether "there exists an overriding legitimate business purpose such that the practice is necessary to the safe and efficient operation of the business." Robinson, 444 F.2d 791, 798 (4th Cir.), cert. dismissed 404 U.S. 1006 (1971).

40. Gutierrez, 838 F.2d at 1040.

41. H.R. 123, 102d Cong., 1st Sess. (1991); S. 434, 102d Cong., 1st Sess. (1991). As of February, 1992, neither Bill had been enacted.

42. Id.

43. Id. 
requires the use of a language other than English." 44 However, "actions, documents, or policies that are purely informational, educational," or that protect "the public health or safety" or "the rights of victims of crimes or criminal defendants" would be exempted under the Bills' definition of official governmental actions. ${ }^{45}$

\section{The English-only Movement}

The Language of Government Act is not the only prospective federal official language legislation to surface in recent years. Several versions of an English Language Amendment to the U.S. Constitution have been proposed as recently as $1988 .{ }^{46}$ These congressional initiatives indicate the growth of the English-only movement since the early 1980's. Numerous constitutional amendments and state statutes enacted since then indicate that the movement has been gaining momentum. ${ }^{47}$

The primary motive of English-only proponents is the maintenance of national unity through a common language. ${ }^{48}$ Many cite the traditional assimilation of immigrants into the English-speaking majority, and fear that the recognition of rights in languages other than English will not promote assimilation but will instead lead to separatism. ${ }^{49}$ The English-only movement also supports legislation limiting governmental powers to use languages other than English in extending services to minority groups, ${ }^{50}$ reasoning that this practice only encourages refusal to adapt to an English-speaking society. ${ }^{51}$

44. Id.

45. Id.

46. H.R. J. Res. 96, 99th Cong., 1st Sess., 131 Cong. Rec. H167 (daily ed. Jan. 24, 1985); S.J. Res. 20, 99th Cong., 1st Sess., 131 Conc. Rec. S468 (daily ed. Jan. 22, 1985). On the history of the ELA in general, see Cordero, supra note 5, at 23; see also PIATt, supra note 2, at 21 for a discussion of the English Language Amendment of 1988.

47. See generally, note 8 for a list of state constitutional amendments and statutes.

48. Cordero, supra note 5, at 23; Barnaby W. Zall \& Sharon McCloe Stein, Legal Background and History of the English Language Movement, in Perspectives on Orficial English 261 (Karen L. Adams \& Daniel T. Brink eds., 1990) [hereinafter Perspectives].

49. See, e.g., Perspectives, supra note 48, at 263, where Zall and Stein liken immigration to entering into a social contract, whereby the immigrant who assimilated by learning English achieved the right to be treated as an equal and participate in the political process; see also, Cordero, supra note 5, at $24 \mathrm{n} .49$, for a description of the various organizations and fears of Hispanic separatism.

50. Cordero, supra note 5 , at 24.

51. Id. at 23 . 
Supporters of official English also cite countries with more than one official language, such as Belgium and Canada, as examples of what they are afraid will happen to the United States if there is not one exclusive official language. ${ }^{52}$ They point to the political and social conflicts historically associated with the language diversity present in those countries. ${ }^{53}$ As this Note will examine, the conflicts in Belgium and Canada have different social and political bases. In the final analysis, it will become clear that certain elements of their language policies would serve the United States well.

\section{RESPONSE TO ENGLISH-ONLY}

Critics of the English-only movement feel that the push for official language legislation is a reaction from the English-speaking majority who fear that they will lose power and influence if the use of minority languages were sanctioned. ${ }^{54}$ They fear that the rights already acquired by language minorities in voting, education, and social services will be in jeopardy if the United States adopts English as the official language. For example, the gains made in voter registration by Hispanics could be annulled if Hispanics no longer had access to voter registration, ballots, and the polls in Spanish. ${ }^{55}$ Critics say this would effectively disenfranchise these people from exercising their constitutional right to vote..$^{.6}$

The educational needs of language minority children to receive instruction in their native language while learning English would be hindered by instructional restrictions. History has shown that instruction only in English, without support from students' native language, only serves to force many out of the educational process ${ }^{57}$ Ironically, many

52. BARON, supra note 2 , at 181 .

53. Id.

54. Roseann Dueñas Gonzalez, In the Aftermath of the ELA: Stripping Language Minorities of Their Rights, in Not Only English, supra note 2, at 49, 50. Gonzalez cites three general conditions in United States' history from which have issued support for restrictive language legislation: war or national crisis, massive immigration, and economic recession.

55. Id. at 55 .

56. Id.

57. Dennis Baron, The Legal Status of English in Illinois: Case Study of a Multilingual State, in Not ONLY ENGLISH, supra note 2, at 13, 24 (noting that "today's bilingual education programs exist because English-only school laws often served as excuses for the schools to permit non-English-speaking students to sink rather than swim"). 
non-English-speaking adults who desire to learn English are denied that opportunity due to a lack of funding for classes and instructors. ${ }^{58}$

While proponents of official English feel that an English-only policy would increase national unity, opponents argue that language restrictions would only serve to further isolate minority groups and create a subclass of citizens.

\section{BeLgium}

Belgium is commonly held out as an example of the instability which results when a nation is divided between various linguistic groups. Political instability in Belgium usually arises out of the conflict between Dutch-speaking Flemings and French-speaking Walloons. ${ }^{59}$ The nation also contains a German-speaking minority whose cultural rights are recognized along with those of the Dutch and French majority. ${ }^{60}$

Belgium is divided into separate language territories, with the capital, Brussels, officially bilingual. One problem has been that the geographic linguistic boundary does not always correspond to demographic reality. Within each language territory, language rights are generally guaranteed only as to the use of the language corresponding to one's own territory. The result has been a nation divided internally by language.

The territorial language division of Belgium arose out of an unstable political and cultural situation in which French had been the dominant language both economically and politically, even though the majority of the population was of Flemish origin. ${ }^{61}$ The dominance of French was guaranteed only so long as the Flemish population was inferior economically. ${ }^{62}$

As Dutch-speaking citizens achieved greater influence, they demanded rights equal to their French-speaking compatriots. The Flemings pressed for the greater linguistic rights which corresponded more eq-

58. On the demand for programs to teach English to Hispanics, see Jon Amastae, Official English and the Learning of English, in Perspectives, supra note 48, at 199, 206.

59. For a general history of Belgium in the context of bicultural division, see Reginald de Schryver, The Belgian Revolution and the Emergence of Belgium's Biculturalism, in Conflict and Coexistence in Belgium 13 (Arend Lijphart ed., 1981).

60. Id. at 31 .

61. Jean-William Lapierre, Le Pouvoir Politique et les Langues 146 (1988).

62. David F. Marshall \& Roseann D. Gonzalez, Una Lingua, Una Patria?: Is Monolingualism Beneficial or Harmful to a Nation's Unity?, in Perspectives, supra note 48, at 30,37 . 
uitably to their population. Following a period of bilingualism, the country was split after 1932 into language regions established according to census data of the time. ${ }^{63}$ With the exception of bilingual Brussels, the language of administration and education would be that of the majority of the locality. ${ }^{64}$

Following the Second World War, the language situation in Belgium once again reached a critical point as the number of French speakers around Brussels surpassed that of Dutch speakers traditionally located there ${ }^{65}$ Brussels itself had long contained a French majority, even though it was officially bilingual. ${ }^{66}$ Fearing a further loss of territory, the Flemish Volksunie (People's Union), which contested the results of the census of 1947, demanded that the linguistic boundary be fixed. ${ }^{67}$ In 1962, it was fixed after difficult negotiations surrounding the linguistic future of several contested municipalities. ${ }^{68}$

The linguistic conflict in Belgium was not completely solved with the resolution of the language boundary disputes. The internal political division which resulted still left behind a certain amount of domestic instability. It would, however, be unfair to state that all of Belgium's problems are based on language. Economic and political factors also play a role. It should be pointed out that despite language issues, Belgium has remained a relatively peaceful and prosperous country.

Belgium is often incorrectly cited by proponents of official English as an example of the detriments which could result if the United States is not united linguistically. However, the situation in the United States is not analogous.

First, the United States is not as drastically divided between competing language groups. On the contrary, the language of the majority is the undisputed de facto official language. Second, linguistic minorities in the United States are not struggling to establish their language as dominant, they merely seek expanded language rights in areas where justice and social reality so demand. While this is partly the case in Belgium, language minorities in the United States are not motivated by the nationalistic or separatist tendencies present in Belgium.

Third, except for native Americans, and Spanish and French speak-

63. LAPIERRe, supta note 61 , at 151 .

64. Id.

65. Id. at 152 .

66. Id.

67. Id. at 154 .

68. Id. 
ers annexed into the United States during its territorial expansion, most linguistic minorities in the United States are immigrants or their descendants. As such, they do not have a common national identity within the United States other than that of any American. The Flemings and Walloons, by contrast, form what amounts to separate nations within their common nation-state.

Still, Belgium's example should shed light on the need for recognition of minority language rights in the United States. Belgium would not be one nation today had the rights sought by excluded language groups not been recognized, and had compromises not been made.

\section{Canada and Quebec}

French and English are the official languages of Canada. The majority of Canadians are English-speaking, but Francophones constitute a majority in the province of Quebec. Some provinces, such as New Brunswick, contain significant Francophone minorities.

Language rights in Canada were established by the British North America Act. ${ }^{69}$ The constitution which followed in 1867 granted the French-speaking population control over provincial matters in Quebec, among which was the question of language. ${ }^{70}$ Under the constitution, the federal government is required to use both French and English in "crucial aspects of . . . operation." " What emerged in Canada "[a]s . . . provinces joined the federation," was that "the tradition of protecting the language and denominational rights of linguistic and religious minorities by special constitutional collective rights was continued where, prior to confederation, these groups had enjoyed such autonomy." 72

The Official Languages Act of 1969 affirmed that both French and English are the "official languages of Canada for all purposes of the Parliament and government of Canada and possess and enjoy equality of status and equal rights and privileges as to their use in all the institutions of Parliament and the government of Canada." 73 As a

69. Leslie Green, Are Language Rights Fundamental?, 25 Oscoode Hall. L.J. 639, 639 (1987).

70. Joseph E. Magnet, Canadian Perspectives on Official English, in Perspectives, supra note 48 , at 53,53 .

71. Id., referring to the Constitution Act, 1867 (U.K.), 30 \& 31 Vict., c.3, s.133. Magnet also states " $[w]$ here the provincial minorities are significant in size, constitutional protection extend equally to provincial government operations, and also to religious schools.

72. Id.

73. Milton J. Esman, The Politics of Official Bilingualism in Canada, in Language Policy, supra note 2 , at $45,47$. 
consequence, all persons have the right to communicate with and receive communications from the federal government in either French or English. Moreover, Francophones employed in the civil service have the right to work in French. ${ }^{74}$

But as demographic changes led to a decline in the number of Francophones in Quebec, fears that Quebec would lose its French culture and heritage increased..$^{75}$ Quebec's economy was dominated by Anglophone business, and Francophones were excluded from senior management. ${ }^{76}$ Support for the separatist Parti-Québecois grew as a response to the perceived lack of concern shown by the rest of Canada for the interests of French-speaking Quebeckers.

A referendum on independence for the province held in the early 1980 's failed to yield the necessary support for separation from Canada, but the results did have an effect on future federal compromises with Quebec on language and cultural issues. Quebec passed legislation which confirmed and strengthened French as the official language of the province, both in government and commerce."

The Canadian constitution was revised in $1982 .{ }^{78}$ Among the revisions was a Charter of Rights and Freedoms, which confirmed constitutional language rights. ${ }^{79}$ Paragraph 23, for example, guarantees the right of Canadian citizens to have their children educated in the official language of their choice where warranted by substantial demand. ${ }^{80}$ The rights of all to communicate with the federal government and to receive services therefrom in either official language was confirmed in the new constitution $^{81}$ and made enforceable in the courts. ${ }^{82}$

While debate on the future of Canadian unity and cultural recognition continues, the situation has improved considerably since the 1980's. Canada has been described as bilingual in the center and

74. Magnet, supra note 70, at 55. See also Esman, supra note 73, at 50 .

75. Magnet, supre note 70 , at 55 . Cited by the author are higher mortality and lower birth rates, and the tendency of immigrants to assimilate into the Englishspeaking community.

76. Id.; see also Esman, supra note 73, at 55.

77. E.g., La Loi 22 (Langue officielle), L.Q. 1974, c. 6, as rep. Charte de la Langue Francaise, L.R.Q. 1977, c. C-11. See also Esman, supra note 73, at 58.

78. Constitution Act, 1982, being Schedule B of the Canada Act 1982 (U.K.), 1982 , c. 11 .

79. Canadian Charter of Rights and Freedoms, Part I of the Constitution Act, 1982, being Schedule B of the Canada Act 1982 (U.K.), 1982, c. 11 [hereinafter Charter].

80. Id.; see also Esman, supra note 73, at 63 .

81. Charter, supra note 79.

82. Id. 
unilingual in the provinces, where limited and pragmatic concessions are made to official language minorities. ${ }^{83}$

Complete harmony, of course, does not exist. The current situation does not satisfy either the Anglophone minority in Quebec, who find that their rights to use English are greater on a federal level than on a local one, or the Anglophone majority in the rest of the country, who resent bearing the costs of providing bilingual federal government for a French-speaking minority.

What must be recognized is that the Francophone minority reacted, and will continue to react, to the disadvantaged position in which they found themselves. Namely, Francophones were discriminated against on a wide scale, even in the province in which they were still a majority. The compromises which have been made have kept the peace and have preserved for the greatest portion of the population the linguistic and cultural rights which will promote harmony in the future.

Canada provides the United States with the best available example of how language policy can help alleviate the pressures created by language diversity. The experiences of Canada should serve as a warning to language policymakers in the United States.

First, the United States needs to recognize the important role which language plays in all segments of society. Both proponents of English-only and minority language groups are concerned with a possible loss of their language rights. Rather than implement an official language policy which would strengthen the role of English to the detriment of other languages, the United States should follow the Canadian example and provide greater guarantees of language rights. The roles of both sides of the English-only movement would thereby be strengthened.

Second, the example of Quebec demonstrates that language groups would rather decide for themselves how to use their language. Although there has been no indication yet of separatist desires among language minorities in the United States, the Canadian example shows that restrictive language policies provide no assurances for the continued dominance of a language not preferred by the population. The recognition of French in Quebec has significantly calmed the clamor for Quebec independence which arose as a consequence of anti-French policies.

Third, minority language children in the United States are often severely disadvantaged when subjected to English-only education. Be-

83. Esman, supra note 73 , at 63 . 
cause of the federal courts' refusal to recognize a definite right to bilingual education, not all states have enacted statutes guaranteeing at least a basic right to bilingual education. In Canada, extensive education rights are granted to language minorities.

Certain aspects of Canadian language policy, however, are not applicable or necessary to the United States' situation. A bilingual federal government or civil service, for example, would be impracticable and is not needed to protect the rights of language minorities in the United States. What is needed instead are legislation and policies which ensure language minorities greater access to the government and services which are their right. Minority language services where warranted would provide this access without overburdening the government as a whole.

The United States similarly should not recognize minority languages as official. Except for English, no single language group is numerous enough to warrant such a costly designation. Moreover, such designations could create situations similar to that of the Anglophone minority in Quebec, where English is official on a federal level but not recognized on a provincial one.

\section{Conclusion}

Some scholars have noted that language rights are recognized in important human rights documents. ${ }^{84}$ These provisions serve to underscore the importance that language rights should be accorded in the United States. That one language is dominant is to the country's credit because unity of language can promote unity of nation. However, this is true only when the groups which use that language are confident that they are not being forced to abandon their own language and culture.

The examples of Belgium and Canada show that discrimination on the basis of language leads to discord. They also show that this discord can in large part be avoided by the intelligent use of language policy.

First, the United States should avoid language policies which are discriminatory or which effectively remove the participation of language minorities from society. Second, national unity is best promoted when cultural and linguistic diversity are not discouraged. The repression of linguistic minorities will only lead to a divisive backlash.

The United States is not threatened with the disappearance of its English-language tradition. The reality is that the United States is a

84. For example, Magnet, supra note 70, at 56; Zoglin, supra note 7; PIATT, supra note 2 , at 162 . 
multilingual society. Minorities will continue to learn and use English as long as success within American society demands it. The greatest threat to this voluntary assimilation are policies which repress those who have not yet achieved it, because the unity of a nation stems from the will of its people and their need to act in concert, not from an official language.

Gregory M. Balmer*

- J.D. Candidate, 1993, Indiana University School of Law-Indianapolis. 